\title{
Production Functions and Input Elasticities in the Construction of Low -Cost Housing : A Comparison of Building Firms in Pakistan with Firms in Five other Countries
}

\author{
EHSAN AHMED ${ }^{*}$
}

\begin{abstract}
In this study, data relating to construction firms of five developing countries are analysed to explore the possibilities of substitution between capital and labour and between skilled and unskilled labour. The study concludes that, in general, both the elasticities are quite low.
\end{abstract}

The population of the urban areas of the developing countries has arisen tremendously during the last three decades. One of the major reasons for this growth is migration due to the differential in incomes, job opportunities, and living styles between cities and rural areas. This rapid growth has put a strain on all cities. Millions do not have a proper place to live and public utilities often do not exist or are negligible. The problem is greatest in the larger Pakistani cities of Karachi, Lahore, Faisalabad, Peshawar and Rawalpindi.

In order to have a thorough look at the problem, a study was sponsored by the U.S. Agency for International Development. The households, builders and construction workers were interviewed in six cities. ${ }^{1}$ This paper is mainly based on the survey of building firms. Our objective is to estimate production functions and input slasticities in the supply of low-cost housing.

Before we discuss the nature of the 1979 Survey in Rawalpindi, it is important to understand the construction industry in Pakistan. According to one official report, the construction industry in Pakistan generally can be classified according to either the size of the firms or the nature of construction, the level of technical

*The author, who is associated with Michigan State University, is indebted to Professor W. Paul Strassmann of that university for helpful suggestions during all stages of this paper. Thanks are also due to Professor Daniel B. Suits of Michigan State University for his comments, though the responsibility of errors lies wholly with the author. The author is also indebted to his colleagues, Nimal Gunatilleke and Manenga Ndulo for their help in the surveys. Also thanks to Ting-ing Ho for computer programming and Miae Evans for skillful typing. Special compliments are to author's wife, Dotte, for her patience and support during the time that this study was carried out. Financial support came from the Office of Urban Development, Agency for International Development.

${ }^{1}$ The cities are Rawalpindi (Pakistan); Colombo (Sri Lanka); Tunis (Tunisia); Nairobi (Kenya); Lusaka (Zambia); and Medellin (Colombia). 
sophistication and the need for technical inputs [7]. There is a relationship between the size of the firm and the technical sophistication of the production process. The building firms can be classified in the following manner:

(1) The first category consists of large firms with professional management, doing work comparable to that of industrialized countries. The firms are engaged in major civil engineering, public works, and high quality private buildings in urban areas. Their technical know how is imported from developed countries and most of their professional management has been trained in advanced countries. Besides possessing highly qualified professionals, these firms use modern and sophisticated equipment.

(2) The second category consists of big contracting firms, which are mainly managed by their owners but are modern or sophisticated only to a certain degree. They are also involved in modern private as well as public construction projects.

(3) The third category is made up of small owner-managed contractors with limited financial and technical resources. They are engaged in less complicated, less capital-intensive private and public construction. The market for their activities is fairly competitive.

(4) The fourth category, according to this report, can be referred to as traditional. The construction job is directly supervised by the owner and there is little technical sophistication.

We have 74 firms in our builders' survey, of which 20 firms are from Pakistan and the remaining from the rest of the countries. ${ }^{2}$ In the Pakistani sample, the categories are not as compartmentalized as mentioned in the above report. In the Pakistani sample, there are three firms which can be placed in Category 1. These firms employ 4,000 to 9,000 workers on construction sites. (The largest one employs about 9,000 workers on site and is incorporated in the public sector.) The number of workers employed off site ranges from 100 to 600 and most of these offsite employees are professionals. Then, there are four more firms which are not as big as the firms in Category 1 but they employ 400 to 4,000 workers on construction sites. The number of off-site workers ranges from 20 to 200 in these firms. About seven firms fall in Category 3 and they employ 50 to 200 workers on site with about 10 to 40 off-site workers. The last six firms fit into Category 4 with 12 to 30 onsite employees and about 2 to 10 off-site workers, with, on average, one or two trained professionals.

${ }^{2}$ The break-down for non-Pakistani firms is as follows: Zambia 1; Colombia 10; Sri Lanka 1; Kenya 24; Tunisia 8. However, all firms did not answer all of the questions. Therefore, the number of non-Pakistan firms varies among different regressions. About 15 firms answered all the questions.
The average number of years for which these firms have been in business is 19 and most of them were established after the independence of Pakistan. The newest firm in our survey is four years old. These builders were asked about building costs of various volumes, and comparisons were made using a plan adapted to local conditions and preferences.

Our first step is to describe the basic floor plan and to compare the costs and on-site employment for single units as well as 10 units in Rawalpindi with those in five non-Pakistani cities. The specified dwelling is rectangular. The roof is flat and supported by six posts of reinforced concrete and a collar beam. The covered area consists of a $12-\mathrm{M}^{2}$ room, a $5.5-\mathrm{M}^{2}$ kitchen, a $1-\mathrm{M}^{2}$ entrance and a $1.5-\mathrm{M}^{2}$ toilet connected to a septic tank. There is a window in each room and the kitchen has running water at a sink. Additional rooms can be built on the upper right or on a roof. The total lot is $77-\mathrm{M}^{2}$ but we do not include the site cost and related infrastructure in our estimates. ${ }^{3}$

The main objective of this paper is to estimate the input elasticities, namely the elasticity of substitution between labour and non-labour and the elasticity of substitution between skilled and unskilled labour. In order to achieve this objective, we will have to estimate the production functions. The production function estimates provide us with the framework which deals with the issues mentioned previously. The production function $\mathrm{Y}=\mathrm{F}\left(\mathrm{X}_{1}, \mathrm{X}_{2}, \ldots \mathrm{X}_{\mathrm{n}}\right)$ defines the relation between the flow of output (Y) and the flow of inputs, namely $\mathrm{X}_{1}, \mathrm{X}_{2}$ and so on. We assume that our production function is continuous and twice differentiable. The output as well as inputs is measurable. The labour input will be measured in physical terms and other inputs in value terms. The production function is also assumed to be homothetic. This implies that the observations are on a single isoquant and that the slope of the isoquant (marginal rate of substitution) is independent of scale and depends only on input proportions. In order to apply this production function theory on our aggregate cross-country data, we assume that the firms in our sample face a competitive local factor market. The relative factor prices of the inputs determine the proportion in which these inputs are used in the production process. This allows for the identification of the production function [4]. We can also introduce the assumption of homogeneous output because each firm has the same specified floor plan. The prices are assumed to be constant in order to keep the model simplified.

Our next step is to define the output and inputs. One way is to define the total output, which in our case is on-site cost + off-site cost + materials. But, in industries, especially manufacturing, the value added is used as a measure of output. It can be computed by subtracting materials from the sum of on-site and off-site

${ }^{3}$ The plan was prepared by the World Bank experts. The engineering and costs details are available from the author. 
costs. Materials are subtracted because they are intermediate goods. The only exception could be imported materials [5]. Labour and capital will be the major inputs. Since data on capital, in a strict sense, are not available in the construction industries of our sample countries, the off-site cost + materials can be a proxy for capital in an alternative formulation. This enables us to estimate Cobb-Douglas and CES production functions. Although this paper will emphasize only CES production function, some of Cobb-Douglas estimates are worth pointing out. Separate regressions are run using total output and value added as dependent variables. CobbDouglas production function with total output as dependent variable provides significant estimates of labour and non-labour coefficients for Pakistan. The sum of elasticities $(\alpha+\beta)^{4}$ is very close to one but for non-Pakistan it is clearly less than one (approximately 0.72). Returns to non-labour factor are higher for Pakistan than for other countries. When value added is used as a dependent variable, the estimated coefficients turn out to be insignificant for Pakistan but significant for the combined sample of all countries. The sum of elasticities is 1.34 , which shows increasing returns to scale. The case of increasing returns to scale in this production function makes the equilibrium conditions more complicated [9]. In this situation, according to Yotopoulos and Nugent [9], factor shares depend not only on real factor prices but also on the demand elasticity for output and the supply elasticities for inputs.

One of the major implications of production estimation is related to the measurement of the degree of substitutability between factor inputs. The substitutability between factor inputs like labour and non-labour is an empirical question. In a Cobb-Douglas production function, the elasticity of substitution $(\sigma)$ between non-labour and labour is restricted to one. Since our estimates gave a good fit for total output, the assumption seems to be fairly good. Now we move on to the Constant Elasticity of Substitution (CES) production function, first presented by Arrow, Chenery, Minhas and Solow (ACMS) [1]. In this production function, the capital-labour proportions do not vary simply as a result of variations in marginal productivities. The ACMS observe that in international cross-sectional studies, the relationship between value added per worker and the wage rate turn out to be significantly different from Cobb-Douglas production function. The CES production function can be written in the following way:

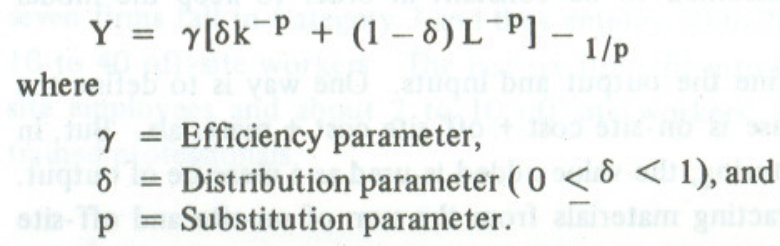

${ }^{4}$ The standard Cobb-Douglas production function is written as $Y=A k_{i}^{\alpha} L_{i}^{\beta} e^{u i}$. The parameter $A$ is the scale parameter. $\alpha$ and $\beta$ are elasticity coefficients, and ui is the disturbance

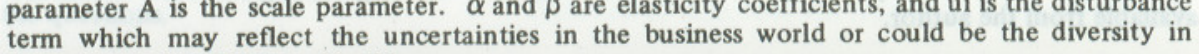
entrepreneurial abilities of builders.
The $\mathrm{p}$ specifies the elasticity of substitution becasue $\sigma=\frac{1}{1+\mathrm{p}}$. If $\mathrm{p}=-1$, the production function becomes linear.

The CES production function can be measured by regressing the log of the average productivity (value added per worker) against the log of the wage rate. The estimated coefficients for the wage rate will actually show the elasticity of substitution between non-labour (capital) and labour. The elasticity of substitution is identical to the elasticity of output per unit of labour. The estimates for this regression are shown in Table 1. The coefficient for WA (average wage rate) shows the elasticity of substitution of labour for non-labour except materials to produce value added. The estimated coefficient of WA for Pakistani data turns out to be 0.87 , significant at the 95 -percent level; for non-Pakistani data, WA is equal to 0.83 , and for the combined data, it is 0.86 . Both are highly significant and are reasonably close to one. If we use output per worker (Table 2), instead of value added per worker, the estimates for Pakistan and non-Pakistan do not change much, but the coefficient of WA for the combined data turns out to be 0.95 , very close to one. If $\sigma=1$, when the relative price ratio ( $\frac{\text { Price of non-labour }}{\text { Price of labour }}$ ) falls by $\mathrm{x} \%$, then the fall

Table 1

The CES Production Functions

Dependent Variable $=$ LOG $\left(\frac{\mathrm{VA}}{\mathrm{N}}\right)$

\begin{tabular}{cccccc}
\hline & Constant & $\begin{array}{c}\text { Coefficient } \\
\text { of WA }\end{array}$ & $\mathrm{R}^{2}$ & $\begin{array}{c}\text { F- } \\
\text { Statistics }\end{array}$ & $\begin{array}{c}\text { No. of } \\
\text { Observations }\end{array}$ \\
\hline $\begin{array}{c}\text { Rawalpindi, } \\
\text { Pakistan }\end{array}$ & $\begin{array}{c}0.77 \\
(1.99)\end{array}$ & $\begin{array}{c}0.87 \\
(2.29)\end{array}$ & 0.19 & 5.19 & 20 \\
& & & & & \\
Five Cities, & & & & & \\
Non-Pakistan & 0.87 & 0.83 & 0.64 & 38.31 & 22 \\
& $(3.30)$ & $(6.19)$ & & & \\
All Data & 0.83 & 0.86 & 0.65 & 75.53 & 42 \\
& $(5.53)$ & $(8.75)$ & & & \\
\hline
\end{tabular}

Source: Building Firms Survey, Summer 1979.

Notes: $\mathrm{t}$-ratios are in the parentheses.

$\mathrm{VA}=($ Value added $)=$ off - site cost + on-site cost .

$\mathrm{N}=$ Labour (skilled + unskilled).

$\mathrm{WA}=$ Average wage rate. 

of $\frac{\text { labour }}{\text { non-labour }}$ demand will be equiproportional and the $\frac{\text { non-labour }}{\text { labour }}$ share will

remain unchanged. If $\sigma<1$, when the relative price ratio ( $\frac{\text { Price of non-labour }}{\text { Price of labour }}$ ) falls by $x \%$, then the fall of $\frac{\text { labour }}{\text { non-labour }}$ is not equiproportional, falling less than

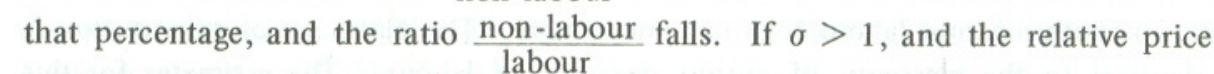

ratio falls by $\mathrm{x} \%$, then the labour ratio falls more than that percentage while the nonlabour share will increase as compared to the share of labour. In Table 1, the $\sigma$ for all three cases is around 0.86 , which is reasonably close to unity. The C-D estimates also suggest the same thing. This means that when the price of labour/non-labour rises by one dollar, the $\frac{\text { labour }}{\text { non-labour }}$ ratio goes up by a factor of 0.85 (0.95 in Table 2 combined regression) and the share of non-labour either remains constant or goes up very slightly. The parameter $\sigma$ is important because it also reflects the wage elasticity of demand for labour. The wage elasticity of demand for labour has two components. The first is the substitution effect, which occurs when non-labour is substituted for labour, while the second is the output effect which depends on the output-price elasticity of demand for labour.

Table 2

CES Production Function with Total Output as Dependent Variable

\begin{tabular}{|c|c|c|c|c|c|}
\hline & Constant & $\begin{array}{c}\text { Coefficient } \\
\text { of WA }\end{array}$ & $\mathrm{R}^{2}$ & $\begin{array}{c}\text { F- } \\
\text { Statistics }\end{array}$ & $\begin{array}{c}\text { No. of } \\
\text { Observations }\end{array}$ \\
\hline $\begin{array}{c}\text { Rawalpindi, } \\
\text { Pakistan }\end{array}$ & $\begin{array}{c}2.22 \\
(5.16)\end{array}$ & $\begin{array}{c}0.80 \\
(1.95)\end{array}$ & 0.13 & 3.72 & 20 \\
\hline $\begin{array}{l}\text { Five-Cities, } \\
\text { Non-Pakistan }\end{array}$ & $\begin{array}{c}0.74 \\
(3.21)\end{array}$ & $\begin{array}{r}0.85 \\
(5.0)\end{array}$ & 0.29 & 23.11 & 54 \\
\hline All Data & $\begin{array}{c}1.04 \\
(4.95)\end{array}$ & $\begin{array}{c}0.95 \\
(5.58)\end{array}$ & 0.30 & 31.79 & 74 \\
\hline
\end{tabular}

Source: Building Firms Survey, Summer 1979.

Notes: $\mathrm{t}$-ratios are in the parentheses.
$\frac{\mathrm{Y}}{\mathrm{N}}=$ total output per worker
$\mathrm{N}$
$\mathrm{Y}=$ total output $=$ on - site cost + off- site cost.
$\mathrm{WA}=$ Average wage rate
$\mathrm{N}=$ Labour.

According to Minasian [6] , based on the assumption of the proponents of the CES production function, the $\sigma$ becomes the wage elasticity of demand when output is held constant, and the $\sigma$ shows the substitution component when output is allowed to vary. The parameter $\sigma<1$ implies that wage elasticity of demand for labour is inelastic. In Table 2, $\sigma$ seems lower for non-Pakistan than for Pakistan (though the difference is not highly significant). The non-Pakistan data have a couple of middleincome countries, namely Colombia and Tunisia. It may be possible that when a country moves from one stage to another stage of development, the $\sigma$ becomes smaller and smaller, which means that substitution between non-labour and labour is becoming difficult. However, thorough empirical investigation may be required to check out this possibility.

Our next step is to modify the regression in Table 1 and to introduce another variable, $\mathrm{Z}$, on the right side of the equation. The variable $\mathrm{Z}$ refers to the materials and off-site costs per worker, hence to the type of the technology and organization used. The resulting estimates are given in Table 3 which shows that the estimated coefficient for WA falls substantially for Pakistan. The Pakistani building firms vary in their technology. The value added per worker is significantly determined by the

\section{Table 3}

\section{The Modified CES Production Function}

Dependent Variable $=$ LOG $(\mathrm{VA} / \mathrm{N})$

Constant $\begin{gathered}\text { Coefficient } \\ \text { of WA }\end{gathered}\left(\mathrm{Z}=\frac{\begin{array}{c}\text { Coefficient of } \\ \text { mater }+ \text { offsite }\end{array}}{\mathrm{N}} \quad \mathrm{R}^{2} \quad \begin{array}{r}\begin{array}{r}\mathrm{F}- \\ \text { Statis- Obser- } \\ \text { tics }\end{array} \\ \text { vation }\end{array}\right.$

Rawalpindi,

$\begin{array}{ccc}-0.26 & 0.55 & 0.53 \\ (0.29) & (2.11) & (4.81)\end{array}$

$0.65 \quad 18.71 \quad 20$

Five Cities,

\begin{tabular}{ccccccc} 
Non-Pakistan & 0.65 & 0.75 & 0.11 & 0.95 & 168.54 & 17 \\
& $(1.85)$ & $(2.88)$ & $(.42)$ & & & \\
\multirow{4}{*}{ All Data } & 0.24 & 0.43 & 0.43 & 0.94 & 36.0 & 37 \\
& $(1.60)$ & $(3.90)$ & $(3.90)$ & & & \\
\hline
\end{tabular}

Notes: (t-ratios are in the parentheses).

VA $($ Value added $)=$ off - site cost + on-site cost.

$\mathrm{N}=$ Labour (skilled and unskilled).

$\mathrm{WA}=$ Average wage rate.

$\mathrm{Z}=$ Off-site cost + Material cost $=$ proxy for capital in our regression 
technology used. Once the $\frac{\text { non-labour }}{\text { labour }}$ ratio is determined, the labour-non-labour substitution becomes more difficult.

Our next step is to estimate the elasticity of substitution between skilled and non-skilled labour. Kmenta [4] has derived a method to estimate $\sigma$ by using Taylor series approximation on the original CES function. His method can be used to regress $\log \left(\frac{\mathrm{Ns}}{\mathrm{Nu}}\right)$ against $\log \left(\frac{\mathrm{Wu}}{\mathrm{Ws}}\right)$. The Ns and Nu are skilled and unskilled labour respectively, and Ws and Wu refer to skilled and unskilled wage rates. The coefficient for $\log \left(\frac{W_{u}}{W_{\mathrm{s}}}\right)$ gives the elasticity of substitution between skilled and unskilled labour. The results are shown in Table 4. The regression for non-Pakistan is significant with $\sigma_{\mathrm{Ns}, \mathrm{Nu}}$ equal to 0.66 , which is clearly less than one, showing that substitution between skilled and unskilled labour is not easy. The measurement of $\sigma$ is a complex measure. As Hamermesh and Grant [2] point out, if labour is classified by its occupation (skilled or unskilled), the wages should be treated as exogenous. This simplifies the matter slightly. Many studies reviewed by Hamermesh and Grant ignore the biases which come up in labour - labour substitution. Capital affects the labour - labour substitution, and biases remain if labour is

Table 4

The Elasticity of Substitution between Skilled and Unskilled Dependent Variables $=$ LOG $(\mathrm{Nu} / \mathrm{Ns})$

\begin{tabular}{|c|c|c|c|c|c|}
\hline & Constant & $\begin{array}{c}\text { Coefficient } \\
\text { of Ws/Wu }\end{array}$ & $\mathrm{R}^{2}$ & $\begin{array}{c}\text { F- } \\
\text { Statistics }\end{array}$ & $\begin{array}{c}\text { No. of } \\
\text { Observations }\end{array}$ \\
\hline $\begin{array}{l}\text { Rawalpindi, } \\
\text { Pakistan }\end{array}$ & $\begin{array}{c}1.74 \\
(1.91)\end{array}$ & $\begin{array}{c}-0.65 \\
(0.50)\end{array}$ & 0 & 0.33 & 20 \\
\hline $\begin{array}{l}\text { Five Cities, } \\
\text { Non-Pakistan }\end{array}$ & $\begin{array}{c}0.31 \\
(1.29)\end{array}$ & $\begin{array}{c}0.66 \\
(2.54)\end{array}$ & 0.27 & 6.06 & 15 \\
\hline All Data & $\begin{array}{c}0.90 \\
(2.39)\end{array}$ & $\begin{array}{c}0.21 \\
(0.47)\end{array}$ & 0 & 0.23 & 35 \\
\hline
\end{tabular}

Source: Building Firms Survey, Summer 1979.

Notes: $\mathrm{t}$-ratios are in the parentheses.

$\mathrm{Nu}=$ Unskilled Labour.

$\mathrm{Ns}=$ Skilled Labour.

Ws $=$ Skilled Wage rate.

$\mathrm{Wu}=$ Unskilled wage rate. not separated from capital. ${ }^{5}$ Hamermesh and Grant suggest that capital should be included in the complete estimation and the appropriateness of the separability assumption should be tested. If capital is excluded from the discussion, the estimates will be biased. The major source of this bias will be the separability assumption. When one kind of wage changes, it not only affects the other types of labour but also the substitutability of capital. However, data on capital are hard to obtain. In Hamermesh-Grant estimates for the U.S., the $\sigma$ is high, a result which is different from ours.

\section{SUMMARY AND CONCLUSIONS}

Economic planners have been trying to solve the problem of slums in the thickly populated cities of the developing countries. Also, their concern has been to provide jobs through low-cost housing programmes. This study estimates production functions for low-cost housing and provides some information about labour-nonlabour and skilled-unskilled elasticities of substitution in six developing countries. The production functions have been estimated for three sets of data, namely, Pakistan, non-Pakistan and all the countries combined. The elasticity of substitution between labour and non-labour turns out to be somewhat low in all cases. The elasticity of substitution between skilled and unskilled labour is too complex to be estimated with the procedures used. The elasticity of substitution between labour and non-labour, however, clearly becomes difficult if the building firms are mechanized and if easily installed materials become readily available.

\section{REFERENCES}

1. Arrow, K. J., H. B. Chenery, B.S. Minhas and R. M. Solow. "Capital-Labour Substitutions and Economic Efficiency". Review of Economics and Statistics. Vol. XLIII. August 1961. pp. 225-50.

2. Hamermesh, D., and J. Grant. "Economic Study of Labor-Labor Substitution and their Implications for Policy". The Journal of Human Resources. Fall 1979. pp. 518-542.

3. Kmenta, Jan. "On Estimation of the CES Production Function". International Economic Review. June 1967. pp. 180-186.

4. Liu, Ta-chung, and George Hildebrand. "Manufacturing Production Function In the U.S. 1957”. Ithaca: New York State School of Industrial and Labor Relations, Cornell University. 1965.

5. McConnaughey, J.S. "Production Functions in Contract Construction for the U.S. 1972”. Ph.D. dissertation, Michigan State University, East Lansing. 1976.

6. Minasian, J. "Elasticities of Substitution and Constant Output Demand Curves for Labor". Journal of Political Economy. June 1961. pp. 260-270.

${ }^{5}$ The trans-log function enables us to test for separability. See [2] 